\title{
Bilateral Breast Abscess in a Newborn Baby
}

\author{
Yenidoğan Bir Bebekte Bilateral Meme Apsesi
}

\author{
Sara Erol', Hasibe Gökçe Çınar², Ayșegül Zenciroğlu', Nurullah Okumuș¹ \\ ${ }^{1}$ Neonatal Intensive Care Unit, Dr. Sami Ulus Maternity and Children Training and Research Hospital, Ankara, Turkey; \\ ${ }^{2}$ Pediatric Radiology Unit, Dr. Sami Ulus Maternity and Children Training and Research Hospital, Ankara, Turkey
}

\section{ABSTRACT}

Mastitis and breast abscess are rarely seen in neonatal period. Neonatal mastitis is generally localized to the breast. A seven-dayold male infant was admitted to the neonatal intensive care unit because of fever and swelling in the bilateral mammary areas. In ultrasound examination, hypoechoic area was monitored in the bilateral retroareolar region. Bilateral breast abscess responded to surgical and medical treatment.

Key words: infant; abscess; mastitis

\section{ÖZET}

Mastit ve meme apsesi yenidoğan döneminde nadiren görülür. Yenidoğan döneminde mastit genellikle memede lokalizedir. Yedi günlük erkek hasta, yenidoğan yoğun bakı ünitesine ateș ve her iki memesinde șișlik nedeniyle bașvurdu. Ultrasonografik incelemede bilateral retroareolar bölgede hipoekoik alan izlendi. Bilateral meme apsesi, cerrahi ve medikal tedavi ile düzeldi.

Anahtar kelimeler: infant; apse; mastit

\section{Introduction}

Mastitis and breast abscess are rarely seen in neonatal period. Neonatal mastitis is defined as evidence of breast inflammation with or without abscess in the first two months of life; with a female: male ratio of approximately 2:1 after two weeks of life ${ }^{1}$. The majority of cases of neonatal mastitis are caused by Staphylococcus aureus; less common causes include gram-negative enteric organisms, anaerobes, and Group B Streptococcus ${ }^{2}$. Although, neonatal mastitis is generally localized to the breast, it can be complicated by extensive cellulitis, necrotizing fasciitis, and osteomyelitis ${ }^{3-4}$. Neonatal mastitis and breast abscess must be treated promptly

Uzm. Dr. Sara Erol, Babür Caddesi No: 44, Altındăg, Ankara, Türkive

Geliş Tarihi: 28.01.2014 • Kabul Tarihi: 12.05.2015 to prevent complications. Herein, we report a newborn case of bilateral breast abscess recovered with medical treatment.

\section{Case Report}

A seven-day-old male infant was admitted to the neonatal intensive care unit because of fever and swelling in the bilateral mammary areas. The mother had no previous history of infection. His mother said that there has been superficial pustules on diaper and axillar region of the baby for two days before fever. On admission, body temperature was $38.4^{\circ} \mathrm{C}$, respiratory rate 64 per minute, and hearth rate 158 per minute. He had approximately $2 \times 2 \mathrm{~cm}$ size swelling lesions in the bilateral retroareolar regions. These lesions were hard on palpation, with increased local temperature, redness of skin and tenderness. Superficial pustule was not observed. Laboratory investigation revealed a hemoglobin of $15.2 \mathrm{~g} / \mathrm{dl}$, a hematocrit of $47.2 \%$, a leukocyte count of $22,000 / \mathrm{mm}^{3}$. Serum C-reactive protein (CRP) level was high $(46 \mathrm{mg} / \mathrm{L}$, normal value: $<10$ $\mathrm{mg} / \mathrm{L})$. Peripheral smear revealed; $64 \%$ neutrophil, $30 \%$ lymphocyte, $6 \%$ monocyte, rare toxic granulation was seen. In ultrasound examination, hypoechoic area was monitored in the bilateral retroareolar region. And dimension of the lesions were $19 \times 15 \mathrm{~mm}$ on the right and $19 \times 12 \mathrm{~mm}$ on the left side. Drainage was performed and ampicillin and cefotaxime treatments were initiated promptly. Lumbar puncture was performed, and examination of the cerebrospinal fluid (CSF) was normal. CSF, blood and abscess cultures were negative but "E.coli" was isolated from urine culture.

At follow-up, patient's fever and inflammatory signs in the breast areas gradually improved with the medical treatment. Antibiotic treatment was given for 2 weeks. The patient was discharged home after full recovery. 


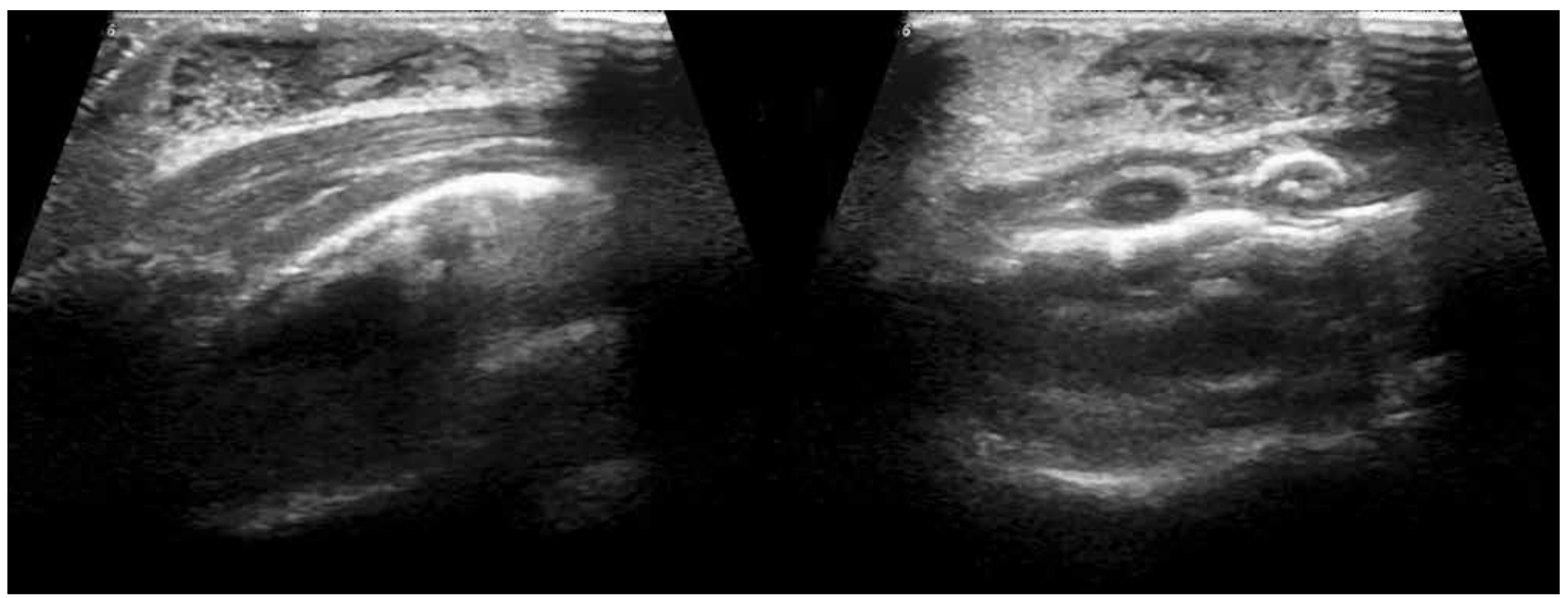

Figure 1. Breast USG showing bilateral abscess.

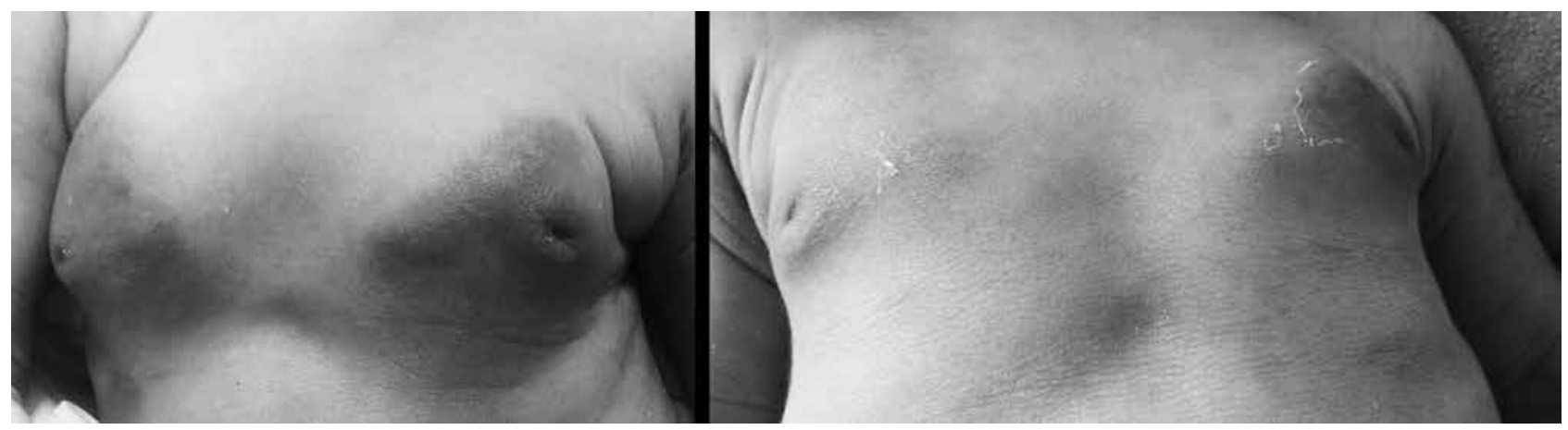

Figure 2. Appearance of the patient before and after treatment.

\section{Discussion}

The pathogenesis of neonatal mastitis is related to the physiologic breast hypertrophy in the term infant, which is induced by maternal hormones, and to the presence of potentially pathogenic bacteria on the skin and/or mucous membranes that spread to the breast parenchyma through the nipple ${ }^{5}$. Manipulation of the neonatal breast to express a nipple discharge ("witch's milk") is a risk factor for breast abscess ${ }^{6}$. In our patient there was no history of maternal infection and manipulation of the infant's breasts.

Neonatal mastitis is usually unilateral and local in nature ${ }^{6}$. Our case had bilateral breast abscess but purulent nipple discharge and enlargement of axillary lymph nodes were not seen either. One-quarter of patients may also have fever $\left(>101^{\circ} \mathrm{F}\left(38.3^{\circ} \mathrm{C}\right)\right.$ such as our patient. Approximately one-half have evidence of skin infection such as superficial pustules or bullae at other parts of the body ${ }^{1}$. Our patient had superficial pustules on the inguinal and axillary region prior to admission.

If the lesion is fluctuant, aspiration (with or without ultrasonographic guidance) should be performed and drainage material also should be sent for Gram stain and culture ${ }^{7}$. However during this procedure, it is important not to injure the underlying breast.

In neonates, it is important to distinguish mastitis from physiologic breast hypertrophy. In contrast to mastitis, in physiologic hypertrophy, the breast bud is neither red nor tender and resolves spontaneously.

No randomized controlled studies have evaluated antibiotic regimens for neonatal mastitis. Recommendations for treatment are based upon the causative pathogens and the response to therapy described in observational studies". The empiric antibiotic choice should be guided by local susceptibility 
patterns and the Gram stain, if one is available. The duration of therapy is 7-14 days, depends on the clinical response of the patient ${ }^{9}$. In conclusion breast abscess is a rare disorder in neonatal period and to the best of our knowledge this is the first case of bilateral breast abscess responded to surgical and medical treatment.

\section{Declaration of Interest}

The authors report no conflict of interest. The authors alone are responsible for the content and writing of the article.

\section{References}

1. Walsh M, McIntosh K. Neonatal mastitis. Clin Pediatr 1986;25:395-9.

2. Efrat M, Mogilner JG, Lujtman M, Eldemberg D, Kunin J, Eldar S. Neonatal mastitis - diagnosis and treatment. Isr J Med Sci 1995;31:558-60.
3. Hsieh WS, Yang PH, Chao HC, Lai JY. Neonatal necrotizing fasciitis: a report of three cases and review of the literature. Pediatrics 1999; 103:53.

4. Michael IK, Howard FH. Osteomyelitis due to penicillinresistant staphylococci in infancy following suppurative mastitis. (Report of a case). J Trop Pediatr 1960;6:19.

5. Sloan B, Evans R. Clinical pearls: neonatal breast mass. Acad Emerg Med 2003;10:269-70.

6. Rudoy RC, Nelson JD. Breast abscess during the neonatal period. A review. Am J Dis Child 1975;129:1031-4.

7. DiVasta AD, Weldon C, Labow BI. The breast: Examination and lesions. In: Emans SJ, Laufer MR, editors. Goldstein's Pediatric \& Adolescent Gynecology, 6th ed. Philadelphia: Lippincott Williams \& Wilkins; 2012. p.405.

8. Fleisher, GR. Infectious disease emergencies. In: Fleisher GR, Ludwig S, Henretig FM, editors. Textbook of Pediatric Emergency Medicine, 5th ed. Philadelphia: Lippincott Williams \& Wilkins; 2006. p.783.

9. Fortunov RM, Hulten KG, Hammerman WA, Mason EO Jr, Kaplan SL. Evaluation and treatment of community-acquired Staphylococcus aureus infections in term and late-preterm previously healthy neonates. Pediatrics 2007;120:937-45. 